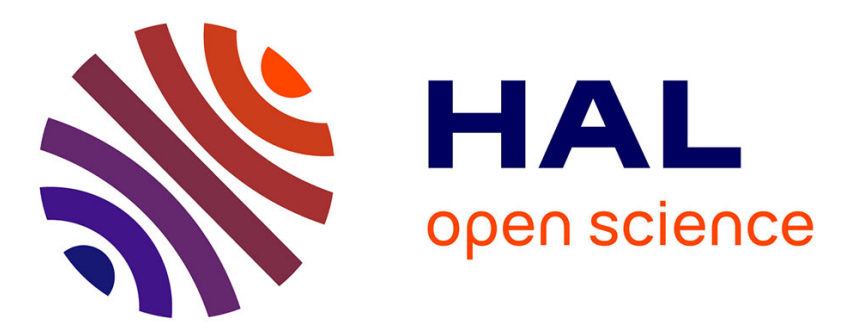

\title{
Functional diversity improves tropical forest resilience: Insights from a long-term virtual experiment
}

Sylvain Schmitt, Isabelle Maréchaux, Jérôme Chave, Fabian Jörg Fischer, Camille Piponiot, Stephane Traissac, Bruno Hérault

\section{To cite this version:}

Sylvain Schmitt, Isabelle Maréchaux, Jérôme Chave, Fabian Jörg Fischer, Camille Piponiot, et al.. Functional diversity improves tropical forest resilience: Insights from a long-term virtual experiment. Journal of Ecology, 2020, 108 (3), pp.831-841. 10.1111/1365-2745.13320 . hal-02394908

\section{HAL Id: hal-02394908 \\ https://hal.umontpellier.fr/hal-02394908}

Submitted on 11 Dec 2019

HAL is a multi-disciplinary open access archive for the deposit and dissemination of scientific research documents, whether they are published or not. The documents may come from teaching and research institutions in France or abroad, or from public or private research centers.
L'archive ouverte pluridisciplinaire HAL, est destinée au dépôt et à la diffusion de documents scientifiques de niveau recherche, publiés ou non, émanant des établissements d'enseignement et de recherche français ou étrangers, des laboratoires publics ou privés. 


\section{Journal of Ecology}

MR SYLVAIN MIKAËL SCHMITT (Orcid ID : 0000-0001-7759-7106)

DR ISABELLE MARÉCHAUX (Orcid ID : 0000-0002-5401-0197)

DR JEROME CHAVE (Orcid ID : 0000-0002-7766-1347)

DR BRUNO HÉRAULT (Orcid ID : 0000-0002-6950-7286)

Article type : Research Article

Editor : Lorena Gomez-Aparicio

\section{Functional diversity improves tropical forest resilience: insights from a long-term virtual experiment}

Sylvain Schmitt ${ }^{*, 1,2}$, Isabelle Maréchaux ${ }^{3}$, Jerome Chave ${ }^{4}$, Fabian Jörg Fischer ${ }^{4}$, Camille Piponiot $^{5}$, Stéphane Traissac ${ }^{6}$, Bruno Herault ${ }^{*}, 7,8$

${ }^{1}$ CNRS, UMR EcoFoG (Agroparistech, Inra, Université des Antilles, Université de la Guyane, Cirad), Campus Agronomique, 97310 Kourou, French Guiana

${ }^{2}$ UMR BIOGECO, Université de Bordeaux, 69 route d'Arcachon, F-33612 Cestas cedex France

This article has been accepted for publication and undergone full peer review but has not been through the copyediting, typesetting, pagination and proofreading process, which may lead to differences between this version and the Version of Record. Please cite this article as doi: 10.1111/1365-2745.13320 
3 AMAP, INRA, Univ Montpellier, IRD, CIRAD, CNRS, F-34000 Montpellier, France

${ }^{4}$ Laboratoire Evolution et Diversité Biologique, UMR5174, CNRS, Université Paul Sabatier, IRD, Toulouse Cedex 9, France

${ }^{5}$ Université de la Guyane, UMR EcoFoG (Agroparistech, CNRS, Inra, Université des Antilles, Cirad), Kourou, French Guiana

${ }^{6}$ AgroParistech, UMR EcoFoG (CNRS, Inra, Université des Antilles, Université de la Guyane, Cirad), Campus Agronomique, 97310 Kourou, French Guiana

${ }^{7}$ Cirad, Univ Montpellier, UR Forests \& Societies, Montpellier, France

${ }^{8}$ Institut National Polytechnique Félix Houphouët-Boigny (INP-HB), BP 1093, Yamoussoukro, Ivory Coast

* Corresponding authors: sylvain.schmitt@agroparistech.fr ; bruno.herault@cirad.fr 


\section{Abstract}

1. Human activities modify the disturbance regimes of tropical forests. Since tropical forests host high biological diversity, understanding the role of biodiversity in ecosystem recovery pathways and the underlying ecological mechanisms is crucial to predict the fate of tropical ecosystems. Studies relying on regularly-censused forest plots rarely include disturbed forests, are not long enough to assess long-term forest dynamics and often lack repeatability.

2. We used an individual-based model of tropical forest growth to assess the effect of species and functional diversity on long-term ecosystem recovery from disturbance. We manipulated the number of species and functional assemblages across a large number of simulations and simulated different levels of disturbance. To investigate the ecological mechanisms that underlie the effect of biodiversity on forest functioning along recovery pathways, we partitioned the net effect of biodiversity on ecosystem properties into complementarity and selection effects over time.

3. We found that functional diversity improved tropical forest resilience after a disturbance. The complementarity effect dominated soon after the disturbance but was progressively surpassed by a selection effect as more competitive species dominated the forest community. This pattern increased with the intensity of the disturbance.

4. Synthesis. We found that the mechanisms through which biodiversity influences forest functioning depend on the ecosystem state, shifting from a dominant complementarity effect in recently disturbed systems to a selection effect in systems disturbed a long time ago. Our results thus suggest that the time since the last disturbance is a key to understanding biodiversity-ecosystem functioning relationships in tropical forests and can help reconcile previous contrasting results obtained with snapshots of ecosystem state in empirical studies. 


\section{Keywords}

Recovery; Disturbance; Complementarity effect; Selection effect; Biodiversity-ecosystem functioning; Individual-based model; Simulation 


\section{Introduction}

Disturbance regimes in tropical forests are being altered by human activities (Davidson et al., 2012; Lewis, Edwards, \& Galbraith, 2015). The main type of disturbance across the tropics is forest logging, encompassing selective timber harvesting in old-growth forests and wood fuel harvesting mainly in secondary forests (Pearson, Brown, Murray, \& Sidman, 2017). In addition to direct human impacts, global change is modifying regional climates with, for instance, an increase in the frequency and intensity of drought events and associated fires (Davidson et al., 2012) and of convective storms (Negrón-Juárez et al., 2018), both resulting in increased tree mortality rates and forest biomass loss (Phillips et al., 2009; Ibanez et al., 2019).

Even without deforestation, such human-induced disturbances can result in degraded forests in which ecological processes underlying forest dynamics are significantly altered (Ghazoul et al., 2015). Deforestation has attracted worldwide attention, while the consequences of degradation for tropical forest functioning have received far less emphasis (Putz \& Redford, 2010; Simula, 2009). However, forest degradation concerns ten times the amount of forest deforested (Herold et al., 2011). Forest degradation can trigger severe biodiversity loss (Burivalova, Şekercioğlu, \& Koh, 2014), and is estimated to account for 2.1 billion of tons of carbon dioxide emissions per year, or $25 \%$ of the greenhouse gas emissions related to deforestation and forest degradation worldwide (Pearson, Brown, Murray, \& Sidman, 2017). Understanding the drivers of tropical forest resilience, i.e. the forests' ability to resist and recover from disturbances (Gunderson, 2010), is thus important to predict their fate under ongoing global change.

Forest recovery from disturbance can be influenced by various factors. For example, the intensity of the disturbance has been found to largely determine the recovery time of ecosystems, including the recovery of biomass, biodiversity, and tree species composition (de Avila et al., 2015; Burivalova et al., 2014; Rutishauser et al., 2015). Forest composition is also known to influence post-disturbance trajectories, as tree species respond differently to disturbances depending on their functional properties (Hérault et al., 2011). Indeed, a functional shift from resource-acquisitive traits (e.g. high nutrient content and photosynthetic 
capacity) to resource-conservative traits (e.g. high leaf toughness and wood density) has been evidenced along chronosequences of secondary forest succession in the wet tropics (Craven, Hall, Berlyn, Ashton, \& van Breugel, 2015; Poorter et al., 2019; Norden, Chazdon, Chao, Jiang \& Vílchez-Alvarado, 2009). Soil nutrients and dispersal limitation also appear to strongly drive community reassembly and dynamics in early succession before light limitation surpass edaphic constraints (van Breugel et al., 2013; van Breugel, Craven, Lai, Baillon, Turner \& Hall, 2019), imposing a stricter filter on functional diversity (Craven, Hall, Berlyn, Ashton, \& van Breugel, 2018).

Another factor that can influence forest resilience to disturbances is forest diversity itself (Cadotte, Carscadden, \& Mirotchnick, 2011; Ives \& Carpenter, 2007; Loreau \& Mazancourt, 2013). Two mechanisms have been suggested to underlie the effect of biodiversity on ecosystem functioning (Loreau \& Hector, 2001). The complementarity effect results from niche partitioning and facilitation, leading to more efficient use of available resources at the community level. The selection effect describes how more diverse communities have a higher probability of including functionally efficient species. Previous theoretical work (Loreau, 2010), experiments (Cardinale et al., 2009; Cardinale et al., 2007; Huang et al., 2018; Niklaus, Baruffol, He, Ma, \& Schmid, 2017), and observations along natural gradients (Chisholm et al., 2013; Liang et al., 2016; Paquette \& Messier, 2011; Poorter et al., 2017) produced contrasting results regarding the relative importance of complementarity and selection effects. Their relative importance can also vary with succession. Fargione et al. (2007) and Huang et al. (2018) found an increasing effect of complementarity in 10-year and 8-year long grassland and forest biodiversity experiments, respectively. On the contrary, Holzwarth, Rüger \& Wirth (2015) found an increasing selection effect in a simulated temperate forest succession.

Secondary forest successional trajectories can be difficult to predict (Norden et al., 2015), presumably due to land-use history and legacy effects (Arroyo-Rodriguez et al., 2017, N'Guessan et al., 2019). The long-term effects of biodiversity on ecosystem recovery and their underlying mechanisms in tropical forests remain under-documented (van der Sande et al., 2017). Studies relying on forest stand inventories often lack repeatability (Poorter et al., 2017; Schnitzer \& 
Carson, 2016), rarely include disturbed forests (Sist et al., 2015), and are not long enough to assess long-term effects (Hérault \& Piponiot, 2018). Forest simulators have proved useful to investigate the effect of biodiversity on forest functioning through virtual biodiversity experiments (Bohn \& Huth, 2017; Maréchaux \& Chave, 2017; Morin, Fahse, Mazancourt, Scherer-Lorenzen, \& Bugmann, 2014; Morin, Fahse, Scherer-Lorenzen, \& Bugmann, 2011; Sakschewski et al., 2016). However, the problem of representing biodiversity beyond a few plant functional types has long been an impediment to applying this approach to species-rich tropical forests (Kazmierczak, Wiegand, \& Huth, 2014; Köhler \& Huth, 1998; Purves \& Pacala, 2008).

In the present study, we explore the effect of species and functional diversity on long-term tropical forest recovery from disturbances of different levels of intensity using a simulation approach. We take advantage of recent advances in the forest simulator TROLL (Chave, 1999), an individual-based and spatially-explicit model of tropical forest that can simulate high levels of diversity through species-specific parameterization relying on plant functional traits (Maréchaux \& Chave, 2017). We manipulated the number of species and functional identity across a large number of simulations and quantified the net effect of biodiversity on forest properties along recovery pathways. To investigate the underlying ecological mechanisms in greater detail, we partitioned the net effect into complementarity and selection effects. We specifically addressed the following questions: (1) Does tree diversity influence forest recovery from disturbances? (2) If so, which facets of pre-disturbance diversity (taxonomic vs. functional) drive this effect? (3) How does the intensity of the disturbance affect forest recovery? (4) What is the relative importance of complementarity and selection effects along post-disturbance trajectories? We hypothesized that: (i) more diverse forests recover more rapidly from a disturbance event due to higher productivity (Liang et al., 2016; but see Dormann et al., 2019); (ii) functional diversity is more directly linked to forest recovery than species diversity, as it represents forest assembly and function better (Cadotte, Carscadden, \& Mirotchnick, 2011); (iii) forest recovery time increases with an increase in disturbance intensity (Rutishauser et al., 2015); and (iv) biodiversity effects vary along post-disturbance trajectories 
(Holzwarth, Rüger \& Wirth, 2015), with a stronger effect of complementarity soon after the disturbance, as more heterogeneous local conditions can foster niche partitioning (Craven, Hall, Berlyn, Ashton, \& van Breugel, 2018), subsequently surpassed by a stronger selection effect as typically observed in mature forests (Chiang et al., 2016).

\section{Material and Methods}

\section{TROLL Model}

TROLL is an individual-based and spatially explicit model of forest dynamics that uses speciesspecific functional traits to parameterize tree physiological function and demographic processes. A detailed description of the model is given in Maréchaux \& Chave (2017) and is only summarized here. In TROLL, the life cycle (recruitment, growth, seed production, and death) is simulated for individual trees $>1 \mathrm{~cm}$ dbh (diameter at breast height). The light environment in which trees grow is computed within a $1 \mathrm{~m}^{3}$ voxel grid. Each tree is flagged with a species label inherited from the mother tree through the seed. Each species label is associated with a number of species-specific functional traits (Table 1) from which ecophysiological and demographic processes are simulated using relationships taken from the literature. These functional traits can be directly obtained from field measurements. Overall, the model data requirement at the species level and its outputs at the individual level reflect current trait collection efforts and field inventories, respectively. For all our simulations and analyses, we used a parameterization for 163 species based on a comprehensive set of functional trait data gathered from a distributed network of intensively-monitored old-growth forest plots in French Guiana (Baraloto et al., 2010), like in Maréchaux \& Chave (2017). This species pool is representative of the functional composition of a Guyanese forest community that typically shelters many latesuccessional species and few pioneer species (see Fig. 6 in Maréchaux \& Chave, 2017).

Seedlings below the $1 \mathrm{~cm}$ size class are not modeled on an individual basis but are part of a seed/seedling pool. This simulated pool is supplied at each monthly time step by seed dispersal from simulated mature trees inside the simulated plot and by a low external seed rain ( 50 seeds 
per hectare) with a species composition similar to that of an old-growth forest. This generates a local seed bank in every square meter of the ground. A maximum of one seed/seedling per square meter is randomly drawn from this local seed bank, and if enough light is available locally for the selected species to thrive, a tree of that species is recruited. Once established, the tree is defined by its age, dbh, height (h), crown radius (CR), crown depth (CD) and leaf area (LA). Tree geometry is calculated using allometric relationships.

Carbon assimilation is computed every half hour of one representative day per month using the Farquhar, von Caemmerer, and Berry model of photosynthesis (Farquhar, Caemmerer, \& Berry, 1980). Photosynthetic capacities and leaf respiration rate are computed from species-specific leaf nitrogen $(\mathrm{N})$ and phosphorus $(\mathrm{P})$ concentration, and leaf mass per area (LMA; Atkin et al., 2015; Domingues et al., 2010). The net amount of assimilated carbon allocated to growth is then partitioned among the different plant organs using empirical factors. The fraction allocated to woody growth is converted into increments of stem volume using species-specific wood density, while the fraction allocated to leaves is converted into leaf area increments using LMA. Leaf demography is simulated using species-specific leaf lifespan derived from LMA. Here we did not use the same relationship between LMA and leaf lifespan as in Maréchaux \& Chave (2017), as we found that it underestimated leaf lifespan in low LMA species. We consequently designed a new leaf lifespan allometry, specific to tropical tree species that is used throughout this study (see Appendix S1). Natural tree deaths are stochastic events and their rate is negatively correlated with wood density in TROLL, as observed pan-tropically (Kraft \& Ackerly, 2010; Poorter et al., 2008; Wright et al., 2010) and locally (Aubry-Kientz, Hérault, AyotteTrépanier, Baraloto, \& Rossi, 2013). Additionally, trees can die due to carbon starvation or treefall. Below-ground processes, herbaceous plants, epiphytes and lianas are not simulated.

The source code is written in $\mathrm{C}++$, version 2.3 .1 used in this study is available at https://github.com/TROLL-code/TROLL. The simulated forest dynamics were validated against observations of both forest composition (e.g. species relative abundance, trait distribution), functioning (e.g. gross primary productivity), and structure (e.g. tree density, plot biomass, tree 
size distribution) made in secondary and mature forest sites in French Guiana (Maréchaux \& Chave, 2017).

Implementing a mechanistic disturbance module in an individual-based model is challenging since disturbances are diverse in tropical forests and can affect individual tree or species depending on specific features (De Laender et al., 2016). For instance, species-specific wood density and tree diameter are key species features in selective logging whereas species hydraulic strategies will influence drought-induced tree mortality (Garcia-Valdés, Bugmann \& Morin, 2018; Anderegg et al., 2016). Although tree mortality rates appear to be increasing in tropical forests, the underlying causes remain poorly understood, and predicting tree mortality based on physiological principles and functional traits remains a formidable challenge (Anderegg et al., 2016; McDowell et al., 2018; Aleixo et al., 2019). For the sake of parsimony, we implemented a module of random disturbance in the TROLL model. In so doing, we studied the effect of disturbance intensity without directionally impacting forest structure and composition.

The module works as follows: at a given iteration $\operatorname{disturb}_{\text {iter }}$, individual trees are randomly picked, independently of particular individual or species-specific properties. Selected individuals are then removed without triggering a treefall to control disturbed biomass volume. The operation is repeated until the cumulative basal area of removed trees reaches the targeted threshold ( disturb $_{\text {intensity }}$ ). We acknowledge that this module depicts a particular type of random disturbance, but this is a first test case to explore the response of forest biodiversity on tropical forest resilience to disturbance. Future versions of TROLL could build on this random disturbance module to include more mechanistic details and explore the effect of different disturbance types (for more details, see the Discussion section).

\section{Simulation experiment}

To assess the role of biodiversity in forest recovery from disturbance, we simulated forest trajectories with different levels of disturbance intensity (distur $\left.b_{\text {intensity }}\right)$ and tree community compositions. For each simulation, we first simulated forest regeneration from bare soil for 600 years (pre-disturbance step). We then simulated the disturbance described above (disturb ${ }_{\text {iter }}$ ), 
and then let the simulated forest community recover freely from the disturbance for a further

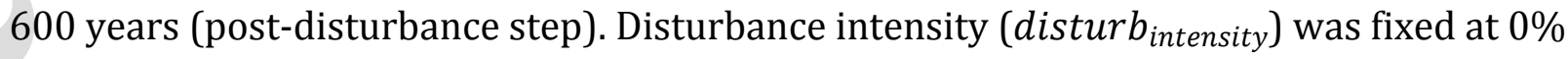
(control), 25\%, 50\% or 75\% of basal area loss. For each level of disturbance intensity, we ran 60 simulations differing in the original number of species (species richness $S R \in\{5,25,125\}$ ) and in floristic composition. For each level of species richness, we first created 1000 virtual communities by randomly picking the desired number of species among the pool of 163 parameterized species. Then, among the 1000 communities, we selected 20 with a wide range of functional trait convex hull volumes CVH (Cornwell, Schwilk, \& Ackerly, 2006) but with a community mean $(C M)$ close to the one of the regional species pool $\left(C M_{L M A}=115 \pm 19 \mathrm{~g} \cdot \mathrm{m}^{-2}\right.$, $C M_{\text {wsg }}=0.73 \pm 0.07$ g.cm ${ }^{-3}, C M_{\text {dmax }}=0.37 \pm 0.1 \mathrm{~m}, C M_{\text {hmax }}=40 \pm 11 \mathrm{~m}$, Baraloto et al., 2010 ) in order to control for average functional composition. This led to 240 simulations with different community composition and disturbance intensity $(3 \mathrm{SR} * 20 \mathrm{CVH} * 4$ levels of disturbance intensity).

\section{Analysis}

\section{Quantifying simulated community diversity}

Species and functional diversities were assessed for each simulation just before the disturbance, i.e. at the end of the pre-disturbance simulation step, with species richness $(S R)$ and functional diversity indices (FDiv, the volume of the functional space occupied by the community; FEve, the regularity of the distribution of abundance in this volume; Villéger, 2008) using the FD R package (Laliberté \& Legendre, 2010). To compute these indices, we used the traits listed in Table 1, which are related to the main independent economics spectra identified in Neotropical forests (Baraloto et al., 2010). Initial species pools resulted in a wide range of values of functional diversity indices after 600 years of pre-disturbance simulation (FDiv ranged from 0.4 to 1.0 and FEve from 0.1 to 0.8 ). 


\section{Ecosystem recovery from disturbance}

Simulated tropical forests were characterized in terms of changes in ecosystem properties regarding (i) forest structure (aboveground biomass, $A G B$ in $M g C . h a^{-1}$; basal area, $B A$ in $m^{2}$. $h \mathrm{a}^{-1}$; total number of stems, $N$; number of stems above $10 \mathrm{~cm}$ dbh, $N 10$; number of stems

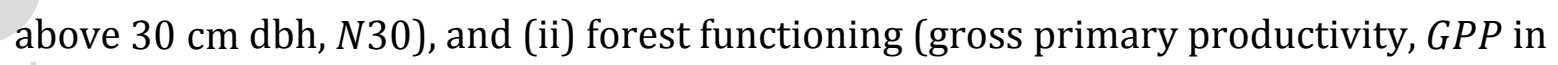
$M g C . h a^{-1}$; net primary productivity, NPP in $M g C . h a^{-1}$; tree autotrophic day-time respiration, Rday in $\mathrm{MgC.ha}^{-1}$; tree autotrophic night-time respiration, Rnight in $\mathrm{MgC.ha}^{-1}$ ).

The recovery of the simulated forest at time $t$ regarding a given property $X, R_{x}(t)$, was defined relative to an undisturbed baseline:

$$
R_{x}(t)=\frac{X_{D}(t)}{X_{C}(t)}
$$

where $X_{D}(t)$ and $X_{C}(t)$ are the values of ecosystem property $X$ at time $t$ in the disturbed simulation $\left(\text { disturb }_{\text {intensity }}=25 \%, 50 \%, 75 \%\right)_{\text {) and in the control simulation }}$ (distur $_{\text {intensity }}$ $=0 \%$ ), respectively (Fig. 1). Note that the variability among replicated simulations with the same set up, due to demographic stochasticity in the model, is low enough to assume that a given simulation is representative of the community properties and dynamics for an initial species pool and disturbance intensity (Maréchaux \& Chave, 2017).

When $R_{x}(t)$ approaches $R_{e q}=1$, the disturbed and control systems are considered equivalent, indicating perfect recovery of $\mathrm{X}$. We then calculated the Euclidean distance to this state of perfect recovery as $d_{x}(t)=\sqrt{\left(\mathrm{R}_{\mathrm{eq}}-R[X(t)]\right)^{\wedge} 2}$ (Fig. 1). To capture the temporal dimension of resilience, we integrated $d_{x}(t)$ over time, which quantifies the cumulative difference between disturbed and control runs, as illustrated by the grey area in Fig. 1. We finally computed the inverse of this area as an index of ecosystem resilience, hereafter denoted $I_{R}$, so that a higher $I_{R}$ reflects greater resilience: 


$$
I_{R}(X)=\left(\int_{t=\text { disturb }_{\text {iter }}}^{t=\text { distur }_{\text {iter }}+600} d_{x}(t) \cdot d t\right)^{-1}
$$

Distance to equilibrium $d_{x}$ and resilience index $I_{R}$ were calculated in a multi-dimensional space for the two sets of ecosystem property values: (i) forest structure $(A G B, B A, N, N 10$, and $N 30)$ and (ii) forest functioning (GPP, NPP, Rday, and Rnight).

\section{Biodiversity effect}

We tested the influence of three factors on the resilience index $I_{R}$ : pre-disturbance species richness $(S R)$, functional evenness (FEve) and functional diversity (FDiv) as follows:

$$
\log \left(I_{R}\right) \sim N\left(\Theta_{S R}+\Theta_{F E v e} \times \text { Feve }+\Theta_{F D i v} \times F d i v ; \sigma^{2}\right)
$$

where $\Theta_{S R}$ is a vector of three parameters corresponding to the three levels of species richness, $\Theta_{F E v e}$ and $\Theta_{F D i v}$ model the effect of, respectively, Feve and Fdiv on $\log \left(\mathrm{I}_{\mathrm{R}}\right)$ under a normal law of variance $\sigma^{2}$. The analysis was conducted twice for each level of disturbance $(25 \%, 50 \%$ and $75 \%$ of basal area loss): once with forest structure properties and once with forest functioning properties. We used the Akaike information criterion (AIC) to select the final, most parsimonious models. The ecosystem resilience index $I_{R}$ was log-transformed to improve the normality of the residuals.

For each ecosystem property $X$, we investigated the effect of biodiversity and its variation along post-disturbance trajectories. The net effect of biodiversity $(N E)$ on ecosystem property $X$ is defined as the difference between the ecosystem property $X$ of the simulated mixed-species community and the one expected under the null hypothesis. The latter would mean that there is no effect of biodiversity, i.e. that ecosystem property $X$ for the mixed-species community equals the abundance-weighted sum of that in monocultures (Loreau \& Hector, 2001). To this end, we simulated a monoculture of each of the 163 species and for each level of disturbance leading to 652 simulations of monocultures. 
We then partitioned this net biodiversity effect into complementarity and selection effects using the partitioning procedure of Loreau \& Hector (2001):

$$
\begin{gathered}
N E=C E+S E(3) \\
C E=S R * \overline{\Delta R X} \bar{M}(3 a) \\
S E=S R * \operatorname{cov}(\Delta R X, M)(3 b)
\end{gathered}
$$

where $S R$ represents the total number of species, $M$ is the vector of $X$ for the 163 simulated monocultures, and $\Delta R X$ is as follows:

$$
\Delta R X_{s p}=\frac{X_{s p}(\text { mixture })}{X_{s p}(\text { monoculture })}-P_{s p}
$$

where $X_{s p}$ is the value $\mathrm{X}$ for the species $s p$ either in mixture $X_{s p}$ (mixture) or in monoculture $X_{s p}$ (monoculture). $P_{s p}$ is the relative abundance of the species in the mixture. In the absence of disturbance, biodiversity net effect $N E$ can vary over time due to stochasticity. To correctly assess selection and complementarity effects, we normalized $N E$ by the value $N E_{C}$ calculated for the control simulation (disturb intensity $=0 \%$ ) to measure the recovery of the net biodiversity effect $R(N E)$ :

$$
R(N E)=\frac{N E}{N E_{C}}=\frac{S E}{N E_{C}}+\frac{C E}{N E_{C}}
$$

\section{Results}

\section{Biodiversity effect on forest resilience}

As species richness $(S R)$ increased from 5 to 125 species, mean functional diversity varied from $0.76 \pm 0.18$ to $0.96 \pm 0.02$ and mean functional evenness ( $F E v e$ ) varied from $0.46 \pm 0.24$ to $0.64 \pm 0.02$. In the models testing the influence of taxonomic and functional diversities on the resilience index $I_{R}$, species richness $(S R)$ was never retained by the AIC selection procedure, 
whatever the disturbance intensity. Both functional diversity (FDiv) and functional evenness ( $F E v e$ ) were positively related with $I_{R}$, i.e. forest resilience increased with both functional diversity and functional evenness (Fig. 2 and Table 2). Similar results were obtained for all disturbance levels, with higher significance for higher disturbance intensity. The model $R^{2}$ was higher for forest functioning (from 0.27 to 0.51 ) than for forest structure (from 0.18 to 0.27 ) variables. While FDiv was the most significant variable in forest structure models, FEve was the most significant variable in forest functioning models (Table 2).

\section{Post-disturbance trajectories of the biodiversity effect}

The net effect of biodiversity on each ecosystem property was quantified (Table 3) and partitioned into selection and complementarity effects. The net effect was positive for most ecosystem variables, apart for the number of stems above $10 \mathrm{~cm} \mathrm{dbh}$ and the net primary productivity for which the average net effects were negative, albeit weak. We found that the complementarity effect of biodiversity on aboveground biomass increased sharply just after disturbance and remained the dominant effect of biodiversity during the first decades after which it progressively vanished (Fig. 3). When we increased the disturbance intensity, the effect of complementarity showed a steeper increase after disturbance and dominated even longer. On the other hand, the selection effect decreased sharply immediately after the disturbance, and only gradually came to play a more important role, dominating the net biodiversity effect about one century after disturbance. At high disturbance intensity, the net effect of biodiversity on aboveground biomass was still lower than the control 600 years after disturbance (Fig. 3). We found similar results, but with an amplified signal, for basal area $(B A)$ and stem abundance $(N$, see Appendix S3). Finally, forest primary productivity and respiration (GPP, NPP, $R_{d a y}$ and $R_{\text {night }}$ ) recovered within a few years with a dominant complementarity effect. 


\section{Discussion}

Using an individual-based and trait-based model of tropical forest, we assessed the effects of species and functional diversity on long-term forest recovery from different disturbance levels by manipulating the number of species and functional assemblages across a large number of simulations. To investigate the ecological mechanisms that underlie the effect of biodiversity on forest functioning along recovery pathways, we further partitioned the net effect of biodiversity on ecosystem properties into complementarity and selection effects. We found that functional diversity improved tropical forest resilience in our simulations. Complementarity was the dominant effect of biodiversity on ecosystem properties shortly after disturbance but was progressively surpassed by a selection effect, as more competitive species dominated the forest community, a pattern that increased with disturbance intensity. Overall, our results suggest that the time since the last disturbance is a key to understanding the ecological mechanisms that underlie the relationships between biodiversity and ecosystem functioning in tropical forests. This helps reconcile the contrasting results obtained previously with snapshots of ecosystem state in empirical studies.

\section{Functional diversity accelerates tropical forest resilience}

Our results provide strong evidence for a significant positive relationship between functional diversity and forest resilience. In particular, the volume of the functional space occupied by the community (Villéger, Mason, \& Mouillot, 2008), and its evenness, both of which turned out to be major predictors of forest resilience. This may be due to (i) an increased range of species niches that enable post-disturbance successional pathways to unfold rapidly, and (ii) functional dissimilarity reducing competition strength (Loreau \& Mazancourt, 2013). Our results thus support Díaz \& Cabido (2001), who pointed to the under-evaluated importance of plant functional diversity in ecosystem processes, and Zhang, Chen, \& Reich (2012) who highlighted the role of evenness in the productivity of forest ecosystems. The effect of functional diversity increased with increased disturbance intensity, although forest recovery trajectories were longer for more intense disturbances, in agreement with the results of previous short-term 
empirical (Hérault \& Piponiot, 2018) or long-term simulation studies (Hiltner et al., 2018) in the area. Decreased resilience with increased disturbance intensity may result from a more extreme shift of the forest functional composition toward an early-successional composition (CarreñoRocabado et al., 2012) that would impede recovery (Qie et al., 2019). Our model simulations provide new evidence that the high diversity of functional traits in tropical forests can reinforce their resilience under the predicted increase in disturbances in the context of global change.

\section{The mechanisms underlying the effect of biodiversity on forest}

\section{functioning shift along a successional trajectory}

We found that complementarity among species was the prevailing effect of biodiversity on forest functioning for several decades after a disturbance. This is a direct consequence of the appearance of gaps and increasingly heterogeneous light availability, the main limiting resource in dense tropical forests. Species are known to vary widely in their demographic response to light availability depending on their functional strategy (Hérault, Ouallet, Blanc, Wagner, \& Baraloto, 2010; Rüger, Huth, Hubbell, \& Condit, 2009). Pioneer species with productive leaf tissue and light wood tend to rapidly occupy gaps after they open, hence creating a shaded environment where late successional species with more conservative leaf tissue can establish later (Craven, Hall, Berlyn, Ashton, \& van Breugel, 2015). By inducing a higher diversity of shade tolerance and growth response to light in the species pool, species richness fosters forest response to disturbances (Morin et al., 2011). This complementarity effect decreases over time while the selection effect progressively takes over. The reduced complementarity effect can be attributed to the increased abundance of the most competitive late-successional species in a stable canopy with more homogenous light availability (Holzwarth, Rüger \& Wirth, 2015).

\section{Implications of modelling choices and generalizability of the results}

In this study, we used an individual-based forest simulator to jointly simulate biodiversity and ecosystem functioning, and explored the effect of biodiversity on forest resilience over centuries, a timeframe that remains out of reach of most experimental approaches. 
Like any modelling approach, our study has its simplifications and assumptions. Our simulations did not account for the secondary effects of disturbances on community structure, such as damage to surrounding trees or secondary treefalls. This should result in larger disturbance gaps and hence increase the spatial scale at which biodiversity impacts forest resilience (Chisholm et al., 2013; Sullivan et al., 2017). However, it should not modify our main results, as our analyses were conducted at the plot scale (16 ha). Similarly, we assumed that our simulated plots were surrounded by old-growth forests resulting in a continuous seed rain of late-successional species. Yet forest fragmentation can strongly influence forest recovery pathways (Arroyo-Rodriguez et al., 2017), reducing selection and enhancing complementarity effects when dispersal is limited (Leibold, Chase \& Ernest, 2017).

In our simulations, light was the only resource whose variability was explicitly accounted for (Maréchaux \& Chave, 2017). Our analysis thus simulated a situation where aboveground competition for light is greater than the effect of belowground competition for water and nutrients, a reasonable assumption in humid tropical forests, even in early successional stages (van Breugel, Breugel, Jansen, Martínez-Ramos, \& Bongers, 2012). However, competition for water may become stronger if drought intensity and frequency increase in the tropics (Duffy, Brando, Asner, \& Field, 2015). The same remark applies to nutrient competition given increased human-induced nutrient imbalances (Peñuelas et al., 2013). Species richness has been shown to stabilize ecosystem growth and mortality in tropical plantations undergoing increasing hydric stress (Hutchison, Gravel, Guichard, Potvin, 2018). We would expect a stronger role of complementarity through hydrological and edaphic niche partitioning under more heterogeneous water availability (Baltzer, Thomas, Nilus, \& Burslem, 2005; Jucker et al., 2018; Silvertown, 2004), and more generally under more heterogeneous environmental conditions. However, under long-term drier-conditions, we would expect selection to have a stronger effect, as more drought-tolerant taxa progressively become more dominant (Sakschewski et al., 2016, Esquivel-Muelbert et al., 2019). Here, we used traits identified as key predictors of ecological functions in Neotropical forests (Baraloto et al., 2010), but other traits, e.g. hydraulic traits such as vulnerability to cavitation or leaf water potential at turgor loss point, play an important role 
in resilience to specific disturbances such as drought (Maréchaux et al., 2018; Santiago et al., 2019). We hope to include these other facets of functional diversity in future contributions, as more data are becoming available for these physiological traits.

More generally, we simulated random disturbances, and our findings could differ for other types of disturbances (Radchuck et al., 2019). For instance, selective logging typically targets a few species, which could favor complementarity over selection if dominant species are repeatedly chosen. Repeated disturbances such as periodic harvesting, one of the main causes of degradation in tropical forests, would also increase the prevalence of early recovery stages during which complementarity plays the main role. Other natural disturbances do affect tropical forests, including droughts, which can impact larger trees (Bennett, McDowell, Allen \& Anderson-Teixeira, 2015; but see Enquist \& Enquist, 2011 or Fauset et al., 2012), fire, which typically impacts smaller trees (Cochrane \& Schulze, 1999), pests, which can impact a single species (Novotny et al. 2002, 2005), or wind-related disturbances, to which softer-wood species can be more vulnerable (Curran, Gersbach, Edwards, \& Krockenberger, 2008; but see Jackson et al., 2019). Previous studies suggested that tree diversity fosters forest resilience to such disturbances (Sakschewski et al., 2016; Guyot, Castagneyrol, Vialatte, Deconchat \& Jactel, 2016; d'Hôte, 2016), in agreement with our findings for random disturbances. However, whether our results concerning long-term recovery trajectories would be the same under these other types of disturbances and their interactions remain to be tested. Ongoing development of the model and improved knowledge of the mechanisms underlying tree vulnerability to various disturbances will allow us to test such hypotheses in future contributions.

\section{Looking at temporal dynamics can unify biodiversity-ecosystem}

\section{functioning studies}

Previous biodiversity-ecosystem functioning studies yielded contrasting results on the relative importance of the different biodiversity effects in tropical forests. While the complementarity effect was identified as the dominant effect in some studies (Huang et al., 2018; Niklaus et al., 2017), the selection effect was identified in others (Tobner et al., 2016; Bauters et al., 2015; 
Maréchaux \& Chave, 2017; Finegan et al., 2015; Lohbeck, Bongers, Martinez-Ramos, \& Poorter, 2016; de Avila et al., 2018). Our results suggest that the mechanisms through which biodiversity influences forest functioning depend to a great extent on the state of the ecosystem and its history of disturbances, with a complementarity effect dominating in recently (i.e. a few decades) disturbed ecosystems and a selection effect surpassing complementarity in systems disturbed a long time ago. In agreement with our results, Huang et al. (2018), Niklaus et al. (2017) and Poorter et al. (2017) did find a stronger complementarity effect in recently disturbed forest sites (8- to 32-year-old plantations or logged plots). On the contrary, other studies of forests disturbed a long time ago and of undisturbed forests showed a dominant selection effect (77-year-old planted forest, Bauters et al., 2015; undisturbed forests, Finegan et al., 2015; 500-year-old simulated forest, Maréchaux \& Chave, 2017). The dominant selection effect observed in plantations by Tobner et al. (2016) or in secondary forests by Lohbeck et al. (2016) could be explained by the recent ecosystem conversion from agricultural fields and fallows, respectively, resulting in the absence of high tree diversity at this stage (see Appendix S2).

Taken together, our results pave the way for a unifying framework to reconcile the apparent contradictions among previous studies, and call for an accurate description of the history of ecosystem disturbances, in agreement with the increasingly recognized importance of legacy effects in shaping forest dynamics and composition (Chazdon et al., 2003; Arroyo-Rodriguez et al., 2017; Levis et al., 2017; Odonne et al., 2019). This opens the way for improved prediction of ecosystem resilience in a context of increasing disturbances and the biodiversity crisis.

\section{Supporting Information}

Appendix S1: Leaf lifespan model

Appendix S2: Biodiversity trajectories

Appendix S3: Post-disturbance trajectories of ecosystem variables

Appendix S4: Variation of forest resilience with taxonomic and functional diversity for different levels of disturbance intensity. 


\section{Acknowledgements}

This study was funded by the GFclim project (FEDER 20142020, Project GY0006894), Investissement d'Avenir grants of the ANR (CEBA: ANR-10-LABEX-0025; TULIP, ref. ANR-10LABX-0041; ANAEE-France: ANR-11-INBS-0001) and a CNES-funded project (BIOMASS).

\section{Authors' contributions}

SS, BH, ST, CP, and IM conceived the study, designed the methodology and analysed model outputs; IM, JC and FF developed the initial model code and ensured its transferability; SS, IM and $\mathrm{BH}$ led the writing of the manuscript. All the authors contributed to the drafts and gave their final approval for publication.

\section{Data availability}

TROLL source code is written in C++ and version 2.3.1 used in this study is available at https://github.com/TROLL-code/TROLL. Species traits used in the simulation experiment are derived from the BRIDGE dataset (Baraloto et al., 2010) available on TRY (Kattge et al., 2011).

\section{References}

Aleixo, I., Norris, D., Hemerik, L., Barbosa, A., Prata, E., Costa, F., \& Poorter, L. (2019). Amazonian rainforest tree mortality driven by climate and functional traits. Nature Climate Change, 9, 384388. doi:10.1038/s41558-019-0458-0

Anderegg, W. R. L., Klein, T., Bartlett, M., Sack, L., Pellegrini, A. F. A., Choat, B., \& Jansen, S. (2016). Meta-analysis reveals that hydraulic traits explain cross-species patterns of drought-induced tree mortality across the globe. Proceedings of the National Academy of Sciences, 113(18), 50245029. doi:10.1073/pnas.1525678113 
Arroyo-Rodríguez, V., Melo, F. P. L., Martínez-Ramos, M., Bongers, F., Chazdon, R. L., Meave, J. A., ... Tabarelli, M. (2017). Multiple successional pathways in human-modified tropical landscapes: new insights from forest succession, forest fragmentation and landscape ecology research. Biological Reviews, 92(1), 326-340. doi:10.1111/brv.12231

Atkin, O. K., Bloomfield, K. J., Reich, P. B., Tjoelker, M. G., Asner, G. P., Bonal, D., ... ZaragozaCastells, J. (2015). Global variability in leaf respiration in relation to climate, plant functional types and leaf traits. New Phytologist, 206(2), 614-636. doi:10.1111/nph.13253

Aubry-Kientz, M., Hérault, B., Ayotte-Trépanier, C., Baraloto, C., \& Rossi, V. (2013). Toward TraitBased Mortality Models for Tropical Forests. PLoS ONE, 8(5), e63678.

doi:10.1371/journal.pone.0063678

Avila, A. L. de, Ruschel, A. R., Carvalho, J. O. P. de, Mazzei, L., Silva, J. N. M., Lopes, J. do C., ... Bauhus, J. (2015). Medium-term dynamics of tree species composition in response to silvicultural intervention intensities in a tropical rainforest. Biological Conservation, 191, 577586. doi:10.1016/j.biocon.2015.08.004

Avila, A. L. de, Sande, M. T. van der, Dormann, C. F., Peña-Claros, M., Poorter, L., Mazzei, L., ... Bauhus, J. (2018). Disturbance intensity is a stronger driver of biomass recovery than remaining tree-community attributes in a managed Amazonian forest. Journal of Applied Ecology, 55(4), 1647-1657. doi:10.1111/1365-2664.13134

Baltzer, J. L., Thomas, S. C., Nilus, R., \& Burslem, D. F. (2005). Edaphic specialization in tropical trees: Physiological correlates and responses to reciprocal transplantation. Ecology, 86(11), 3063-3077. doi:10.1890/04-0598

Baraloto, C., Paine, C. E. T., Poorter, L., Beauchene, J., Bonal, D., Domenach, A. M., ... Chave, J. (2010). Decoupled leaf and stem economics in rain forest trees. Ecology Letters, 13(11), 13381347. doi:10.1111/j.1461-0248.2010.01517.x 
Baraloto, C., Timothy Paine, C. E., Patino, S., Bonal, D., Hérault, B., \& Chave, J. (2010). Functional trait variation and sampling strategies in species-rich plant communities. Functional Ecology, 24(1), 208-216. doi: 10.1111/j.1365-2435.2009.01600.x

Bauters, M., Ampoorter, E., Huygens, D., Kearsley, E., De Haulleville, T., Sellan, G., ... Peters, D. P. (2015). Functional identity explains carbon sequestration in a 77-year-old experimental tropical plantation. Ecosphere, 6(10), 1-11. doi:10.1890/ES15-00342.1

Bennett, A. C., Mcdowell, N. G., Allen, C. D., \& Anderson-Teixeira, K. J. (2015). Larger trees suffer most during drought in forests worldwide. Nature Plants, 1(10), 15139. doi:10.1038/nplants.2015.139

Bohn, F. J., \& Huth, A. (2017). The importance of forest structure to biodiversity-productivity relationships. Royal Society Open Science, 4(1). doi:10.1098/rsos.160521

van Breugel, M., van Breugel, P., Jansen, P. A., Martínez-Ramos, M., \& Bongers, F. (2012). The relative importance of above- versus belowground competition for tree growth during early succession of a tropical moist forest. Plant Ecology, 213(1), 25-34. doi:10.1007/s11258-0110003-3

van Breugel, M., Hall, J. S., Craven, D., Bailon, M., Hernandez, A., Abbene, M., \& van Breugel, P. (2013). Succession of ephemeral secondary forests and their limited role for the conservation of floristic diversity in a human-modified tropical landscape. PLOS ONE, 8(12). doi:10.1371/journal.pone.0082433

van Breugel, M., Craven, D., Lai, H.R. Baillon, M., Turner, B.L., Hall, J.S. (2019). Soil nutrients and dispersal limitation shape compositional variation in secondary tropical forests across multiple scales 107(2) 566-581. Journal of Ecology. doi:10.1111/1365-2745.13126.

Burivalova, Z., Şekercioğlu, Ç. H., \& Koh, L. P. (2014). Thresholds of logging intensity to maintain tropical forest biodiversity. Current Biology, 24(16), 1893-1898. doi:10.1016/j.cub.2014.06.065 
Cadotte, M. W., Carscadden, K., \& Mirotchnick, N. (2011). Beyond species: Functional diversity and the maintenance of ecological processes and services. Journal of Applied Ecology, 48(5), 1079-1087. doi:10.1111/j.1365-2664.2011.02048.x

Cardinale, B. J., Srivastava, D. S., Duffy, J. E., Wright, J. P., Downing, A. L., Sankaran, M., ... Loreau, M. (2009). Effects of biodiversity on the functioning of ecosystems: a summary of 164 experimental manipulations of species richness. Ecology, 90(3), 854-854. doi:10.1890/081584.1

Cardinale, B. J., Wright, J. P., Cadotte, M. W., Carroll, I. T., Hector, A., Srivastava, D. S., ... Weis, J. J. (2007). Impacts of plant diversity on biomass production increase through time because of species complementarity. Proceedings of the National Academy of Sciences of the United States of America, 104(46), 18123-18128. doi:10.1073/pnas.0709069104

Chave, J. (1999). Study of structural, successional and spatial patterns in tropical rain forests using TROLL, a spatially explicit forest model. Ecological Modelling, 124(2-3), 233-254. doi:10.1016/S0304-3800(99)00171-4

Carreño-Rocabado, G., Peña-Claros, M., Bongers, F., Alarcón, A., Licona, J. C., \& Poorter, L. (2012). Effects of disturbance intensity on species and functional diversity in a tropical forest. Journal of Ecology, 100(6), 1453-1463. doi:10.1111/j.1365-2745.2012.02015.x

Chazdon, R. L. (2003). Tropical forest recovery: legacies of human impact and natural disturbances. Perspectives in Plant Ecology, Evolution and Systematics, 6(1-2), 51-71. doi:10.1078/1433-8319-00042

Chisholm, R. A., Muller-Landau, H. C., Abdul Rahman, K., Bebber, D. P., Bin, Y., Bohlman, S. A., ... Zimmerman, J. K. (2013). Scale-dependent relationships between tree species richness and ecosystem function in forests. Journal of Ecology, 101(5), 1214-1224. doi:10.1111/13652745.12132 
Cochrane, M. A., \& Schulze, M. D. (1999). Fire as a Recurrent Event in Tropical Forests of the Eastern Amazon: Effects on Forest Structure, Biomass, and Species Composition. Biotropica, 31(1), 2-16. doi:10.1111/j.1744-7429.1999.tb00112.x

Condit, R. S., Engelbrecht, B. M. J., Pino, D., Perez, R., \& Turner, B. L. (2013). Species distributions in response to individual soil nutrients and seasonal drought across a community of tropical trees. Proceedings of the National Academy of Sciences of the United States of America, 110(13), 5064-5068. doi:10.1073/pnas.1218042110.

Cornwell, W. W. K., Schwilk, D. W. D., \& Ackerly, D. D. (2006). A Trait-Based Test for Habitat Filtering: Convex Hull Volume. Ecology, 87(6), 1465-1471. doi:10.1890/00129658(2006)87[1465:ATTFHF]2.0.CO;2

Craven, D., Hall, J. S., Berlyn, G. P., Ashton, M. S., \& van Breugel, M. (2015). Changing gears during succession: Shifting functional strategies in young tropical secondary forests. Oecologia, 179(1), 293-305. doi:10.1007/s00442-015-3339-x

Craven, D., Hall, J. S., Berlyn, G. P., Ashton, M. S., \& van Breugel, M. (2018). Environmental filtering limits functional diversity during succession in a seasonally wet tropical secondary forest. Journal of Vegetation Science, 29(3), 511-520. doi:10.1111/jvs.12632

Currant, T. J., Gersbach, L. N., Edwards, W., \& Krockenberger, A. K. (2008). Wood density predicts plant damage and vegetative recovery rates caused by cyclone disturbance in tropical rainforest tree species of North Queensland, Australia. Austral Ecology, 33(4), 442-450. doi:10.1111/j.1442-9993.2008.01899.x

Davidson, E. A., De Araüjo, A. C., Artaxo, P., Balch, J. K., Brown, I. F., Mercedes, M. M., ... Wofsy, S. C. (2012). The Amazon basin in transition. Nature, 481, 321-328. doi:10.1038/nature10717

De Laender, F., Rohr, J. R., Ashauer, R., Baird, D. J., Berger, U., Eisenhauer, N., ... Van den Brink, P. J. (2016). Reintroducing Environmental Change Drivers in Biodiversity-Ecosystem Functioning Research. Trends in Ecology and Evolution, 31(12), 905-915. doi:10.1016/j.tree.2016.09.007 
Dhôte, J.-F. (2005). Implication of Forest Diversity in Resistance to Strong Winds. In Forest Diversity and Function (pp. 291-307). Berlin/Heidelberg: Springer-Verlag. doi:10.1007/3-54026599-6_14

Díaz, S., \& Cabido, M. (2001). Vive la différence: Plant functional diversity matters to ecosystem processes. Trends in Ecology and Evolution, 16(11), 646-655. doi:10.1016/S01695347(01)02283-2

Domingues, T. F., Meir, P., Feldpausch, T. R., Saiz, G., Veenendaal, E. M., Schrodt, F., ... Lloyd, J. (2010). Co-limitation of photosynthetic capacity by nitrogen and phosphorus in West Africa woodlands. Plant, Cell and Environment, 33(6), 959-980. doi:10.1111/j.13653040.2010.02119.x

Dormann, C. F., Schneider, H., \& Gorges, J. (2019). Neither global nor consistent: a technical comment on the tree diversity-productivity analysis of Liang et al. (2016). bioRxiv, 524363. doi:10.1101/524363

Duffy, P. B., Brando, P., Asner, G. P., \& Field, C. B. (2015). Projections of future meteorological drought and wet periods in the Amazon. Proceedings of the National Academy of Sciences, 112(43), 13172-13177. doi:10.1073/pnas.1421010112

Enquist, B. J., \& Enquist, C. A. F. (2011). Long-term change within a Neotropical forest: Assessing differential functional and floristic responses to disturbance and drought. Global Change Biology, 17(3), 1408-1424. doi:10.1111/j.1365-2486.2010.02326.x

Esquivel-Muelbert, A., Baker, T. R., Dexter, K. G., Lewis, S. L., Brienen, R. J. W., Feldpausch, T. R., ... Phillips, O. L. (2019). Compositional response of Amazon forests to climate change. Global Change Biology, 25(1), 39-56. doi:10.1111/gcb.14413

Fargione, J., Tilman, D., Dybzinski, R., Lambers, J. H. R., Clark, C., Harpole, W. S., ... Loreau, M. (2007). From selection to complementarity: shifts in the causes of biodiversity-productivity relationships in a long-term biodiversity experiment. Proceedings of the Royal Society B: Biological Sciences, 274(1611), 871-876. doi:10.1098/rspb.2006.0351 
Farquhar, G. D., Caemmerer, S. von, \& Berry, J. A. (1980). A biochemical model of photosynthetic CO2 assimilation in leaves of C3 species. Planta, 149(1), 78-90. doi:10.1007/BF00386231

Fauset, S., Baker, T. R., Lewis, S. L., Feldpausch, T. R., Affum-Baffoe, K., Foli, E. G., ... Swaine, M. D. (2012). Drought-induced shifts in the floristic and functional composition of tropical forests in Ghana. Ecology Letters, 15(10), 1120-1129. doi:10.1111/j.1461-0248.2012.01834.x

Finegan, B., Peña-Claros, M., Oliveira, A. de, Ascarrunz, N., Bret-Harte, M. S., Carreño-Rocabado, G., ... Poorter, L. (2015). Does functional trait diversity predict above-ground biomass and productivity of tropical forests? Testing three alternative hypotheses. Journal of Ecology, 103(1), 191-201. doi:10.1111/1365-2745.12346

García-Valdés, R., Bugmann, H., \& Morin, X. (2018). Climate change-driven extinctions of tree species affect forest functioning more than random extinctions. Diversity and Distributions, 24(7), 906-918. doi:10.1111/ddi.12744

Ghazoul, J., Burivalova, Z., Garcia-Ulloa, J., \& King, L. A. (2015, October 1). Conceptualizing Forest Degradation. Trends in Ecology and Evolution, 30(10), 622-632. doi:10.1016/j.tree.2015.08.001

Grau, O., Peñuelas, J., Ferry, B., Freycon, V., Blanc, L., Desprez, M., ... Hérault, B. (2017). Nutrientcycling mechanisms other than the direct absorption from soil may control forest structure and dynamics in poor Amazonian soils. Scientific Reports, 7(1). doi:10.1038/srep45017

Gunderson, L. (2010). Ecological and human community resilience in response to natural disasters. Ecology and Society, 15(2), 29. doi:10.5751/ES-03381-150218

Guyot, V., Castagneyrol, B., Vialatte, A., Deconchat, M., \& Jactel, H. (2016). Tree diversity reduces pest damage in mature forests across Europe. Biology Letters, 12(4).

doi:10.1098/rsbl.2015.1037

Hérault, B., Ouallet, J., Blanc, L., Wagner, F., \& Baraloto, C. (2010). Growth responses of neotropical trees to logging gaps. Journal of Applied Ecology, 47(4), 821-831. doi:10.1111/j.1365-2664.2010.01826.x 
Herold, M., Román-Cuesta, R., Mollicone, D., Hirata, Y., Van Laake, P., Asner, G. P., ... MacDicken, K. (2011). Options for monitoring and estimating historical carbon emissions from forest degradation in the context of REDD+. Carbon Balance and Management, 6(1), 13. doi:10.1186/1750-0680-6-13

Hérault, B., \& Piponiot, C. (2018). Key drivers of ecosystem recovery after disturbance in a neotropical forest. Forest Ecosystems, 5(1), 2. doi:10.1186/s40663-017-0126-7

Hérault, B., Bachelot, B., Poorter, L., Rossi, V., Bongers, F., Chave, J., ... Baraloto, C. (2011). Functional traits shape ontogenetic growth trajectories of rain forest tree species: Plant traits shape growth trajectory. Journal of Ecology, 99(6), 1431-1440. doi:10.1111/j.13652745.2011.01883.x

Hiltner, U., Huth, A., Bräuning, A., Hérault, B., \& Fischer, R. (2018). Simulation of succession in a neotropical forest: High selective logging intensities prolong the recovery times of ecosystem functions. Forest Ecology and Management, 430, 517-525. doi:10.1016/j.foreco.2018.08.042

Hooper, D. U., Chapin, F. S., Ewel, J. J., Hector, A., Inchausti, P., Lavorel, S., ... Wardle, D. A. (2005). Effects of biodiversity on ecosystem functioning: A consensus of current knowledge. Ecological Monographs, 75(1), 3-35. doi:10.1890/04-0922

Holzwarth, F., Rüger, N., \& Wirth, C. (2015). Taking a closer look: disentangling effects of functional diversity on ecosystem functions with a trait-based model across hierarchy and time. Royal Society Open Science, 2(3), 140541-140541. doi:10.1098/rsos.140541

Huang, Y., Chen, Y., Castro-Izaguirre, N., Baruffol, M., Brezzi, M., Lang, A., ... Schmid, B. (2018). Impacts of species richness on productivity in a large-scale subtropical forest experiment. Science, 362(6410), 80-83. doi:10.1126/science.aat6405

Hutchison, C., Gravel, D., Guichard, F., Potvin, C. (2018). Effect of diversity on growth, mortality, and loss of resilience to extreme climate events in a tropical planted forest experiment. Scientific Reports, 8(15443). doi:10.1038/s41598-018-33670-x 
Ibanez, T., Keppel, G., Menkes, C., Gillespie, T. W., Lengaigne, M., Mangeas, M., ... Birnbaum, P. (2019). Globally consistent impact of tropical cyclones on the structure of tropical and subtropical forests. Journal of Ecology, 107(1), 279-292. doi:10.1111/1365-2745.13039

Ives, A. R., \& Carpenter, S. R. (2007). Stability and diversity of ecosystems. American Association for the Advancement of Science. Science, 317(5834), 58-62. doi:10.1126/science.1133258

Jackson, T., Shenkin, A., Kalyan, B., Zionts, J., Calders, K., Origo, N., ... Malhi, Y. (2019). A New Architectural Perspective on Wind Damage in a Natural Forest. Frontiers in Forests and Global Change, 1(13). doi:10.3389/ffgc.2018.00013

Jucker, T., Hardwick, S. R., Both, S., Elias, D. M., Ewers, R. M., Milodowski, D. T., ... Coomes, D. A. (2018). Canopy structure and topography jointly constrain the microclimate of human-modified tropical landscapes. Global Change Biology, 24(11), 5243-5258. doi:10.1111/gcb.14415

Kattge, J., Diaz, S., Lavorel, S., Prentice, I. C., Leadley, P., Bönisch, G., ... Wirth, C. (2011). TRY - a global database of plant traits. Global Change Biology, 17(9), 2905-2935. doi:10.1111/j.13652486.2011.02451.x

Kazmierczak, M., Wiegand, T., \& Huth, A. (2014). A neutral vs. non-neutral parametrizations of a physiological forest gap model. Ecological Modelling, 288, 94-102.

doi:10.1016/j.ecolmodel.2014.05.002

Köhler, P., \& Huth, A. (1998). The effects of tree species grouping in tropical rainforest modelling: Simulations with the individual-based model FORMIND. Ecological Modelling, 109(3), 301-321. doi:10.1016/S0304-3800(98)00066-0

Kraft, N. J. B., \& Ackerly, D. D. (2010). Functional trait and phylogenetic tests of community assembly across spatial scales in an Amazonian forest. Ecological Monographs, 80(3), 401-422. doi:10.1890/09-1672.1

Laliberté, E., \& Legendre, P. (2010). A distance-based framework for measuring functional diversity from multiple traits. Ecology, 91(1), 299-305. doi:10.1890/08-2244.1 
Laurans, M., Martin, O., Nicolini, E., \& Vincent, G. (2012). Functional traits and their plasticity predict tropical trees regeneration niche even among species with intermediate light requirements. Journal of Ecology, 100(6), 1440-1452. doi:10.1111/j.1365-2745.2012.02007.x

Leibold, M. A., Chase, J. M., \& Ernest, S. K. M. (2017). Community assembly and the functioning of ecosystems: how metacommunity processes alter ecosystems attributes. Ecology, 98(4), 909919. doi:10.1002/ecy.1697

Lewis, S. L., Edwards, D. P., \& Galbraith, D. (2015). Increasing human dominance of tropical forests. Science, 349(6250), 827-832. doi:10.1126/science.aaa9932

Liang, J., Crowther, T. W., Picard, N., Wiser, S., Zhou, M., Alberti, G., ... Reich, P. B. (2016). Positive biodiversity-productivity relationship predominant in global forests. Science, 354(6309), 196. doi:10.1126/science.aaf8957

Lohbeck, M., Bongers, F., Martinez-Ramos, M., \& Poorter, L. (2016). The importance of biodiversity and dominance for multiple ecosystem functions in a human-modifed tropical landscape. Ecology, 97(10), 2772-2779. doi:10.1002/ecy.1499

Loreau, M. (1998). Separating Sampling and Other Effects in Biodiversity Experiments. Oikos, 82(3), 600. doi:10.2307/3546381

Loreau, M. (2010). Linking biodiversity and ecosystems: towards a unifying ecological theory. Philosophical Transactions of the Royal Society of London. Series B, Biological Sciences, 365(1537), 49-60. doi:10.1098/rstb.2009.0155

Loreau, M., \& Hector, a. (2001). Partitioning selection and complementarity in biodiversity experiments. Nature, 412(6842), 72. doi:10.1038/35083573

Loreau, M., \& Mazancourt, C. de. (2013). Biodiversity and ecosystem stability: A synthesis of underlying mechanisms. Ecology Letters, 16(1), 106-115. doi:10.1111/ele.12073 
Maréchaux, I., Bonal, D., Bartlett, M. K., Burban, B., Coste, S., Courtois, E. A., ... Chave, J. (2018). Dry-season decline in tree sapflux is correlated with leaf turgor loss point in a tropical rainforest. Functional Ecology, 32(10), 2285-2297. do:10.1111/1365-2435.13188

Maréchaux, I., \& Chave, J. (2017). An individual-based forest model to jointly simulate carbon and tree diversity in Amazonia: description and applications. Ecological Monographs, 87(4), 632-664. doi:10.1002/ecm.1271

McDowell, N., Allen, C. D., Anderson-Teixeira, K., Brando, P., Brienen, R., Chambers, J., ... Xu, X. (2018). Drivers and mechanisms of tree mortality in moist tropical forests. New Phytologist, 219(3), 851-869. doi:10.1111/nph.15027

Morin, X., Fahse, L., Mazancourt, C. de, Scherer-Lorenzen, M., \& Bugmann, H. (2014). Temporal stability in forest productivity increases with tree diversity due to asynchrony in species dynamics. Ecology Letters, 17(12), 1526-1535. doi:10.1111/ele.12357

Morin, X., Fahse, L., Scherer-Lorenzen, M., \& Bugmann, H. (2011). Tree species richness promotes productivity in temperate forests through strong complementarity between species. Ecology Letters, 14(12), 1211-1219. doi:10.1111/j.1461-0248.2011.01691.x

Negrón-Juárez, R. I., Holm, J. A., Marra, D. M., Rifai, S. W., Riley, W. J., Chambers, J. Q., ... Higuchi, N. (2018). Vulnerability of Amazon forests to storm-driven tree mortality. Environmental Research Letters, 13(5). doi:10.1088/1748-9326/aabe9f

N’Guessan, A. E., N'dja, J. K., Yao, O. N., Amani, B. H. K., Gouli, R. G. Z., Piponiot, C., ... Hérault, B. (2019). Drivers of biomass recovery in a secondary forested landscape of West Africa. Forest Ecology and Management, 433, 325-331. doi:10.1016/j.foreco.2018.11.021

Niklaus, P. A., Baruffol, M., He, J. S., Ma, K., \& Schmid, B. (2017). Can niche plasticity promote biodiversity-productivity relationships through increased complementarity? Ecology, 98(4), 1104-1116. doi:10.1002/ecy.1748 
Norden, N., Chazdon, R. L., Chao, A., Jiang, Y.-H., \& Vílchez-Alvarado, B. (2009). Resilience of tropical rain forests: Tree community reassembly in secondary forests. Ecology Letters, 12(5), 385-394. doi:10.1111/j.1461-0248.2009.01292.x

Norden, N., Angarita, H. A., Bongers, F., Martínez-Ramos, M., Granzowde la Cerda, I., van Breugel, M., ... Chazdon, R. L. (2015). Successional dynamics in Neotropical forests are as uncertain as they are predictable. Proceedings of the National Academy of Sciences of the United States of America, 112(26), 8013-8018. doi:10.1073/pnas.1500403112

Novotny, V., Basset, Y., Miller, S. E., Weiblen, G. D., Bremer, B., Cizek, L., \& Drozd, P. (2002). Low host specificity of herbivorous insects in a tropical forest. Nature, 416(6883), 841-844. doi:10.1038/416841a

Novotny, V., \& Basset, Y. (2005). Host specificity of insect herbivores in tropical forests. Proceedings of the Royal Society B: Biological Sciences, 272(1568). doi:10.1098/rspb.2004.3023

Odonne, G., van den Bel, M., Burst, M., Brunaux, O., Bruno, M., Dambrine, E., ... Hérault, B. (2019). Long-term influence of early human occupations on current forests of the Guiana Shield. Ecology, 100(10), e02806. doi:10.1002/ecy.2806

Paquette, A., \& Messier, C. (2011). The effect of biodiversity on tree productivity: From temperate to boreal forests. Global Ecology and Biogeography, 20(1), 170-180. doi:10.1111/j.1466-8238.2010.00592.x

Pearson, T. R. H., Brown, S., Murray, L., \& Sidman, G. (2017). Greenhouse gas emissions from tropical forest degradation: an underestimated source. Carbon Balance and Management, 12(1). doi:10.1186/s13021-017-0072-2

Peñuelas, J., Poulter, B., Sardans, J., Ciais, P., van der Velde, M., Bopp, L., ... Janssens, I. A. (2013). Human-induced nitrogen-phosphorus imbalances alter natural and managed ecosystems across the globe. Nature Communications, 4(1), 2934. doi:10.1038/ncomms3934 
Phillips, O. L., Aragão, L. E. O. C., Lewis, S. L., Fisher, J. B., Lloyd, J., López-González, G., ... TorresLezama, A. (2009). Drought sensitivity of the amazon rainforest. Science, 323(5919), 1344-1347. doi:10.1126/science.1164033

Phillips, O. L., Heijden, G. van der, Lewis, S. L., López-González, G., Aragão, L. E. O. C., Lloyd, J., ... Vilanova, E. (2010). Drought-mortality relationships for tropical forests. New Phytologist, 187(3), 631-646. doi: 10.1111/j.1469-8137.2010.03359.x

Piponiot, C., Cabon, A., Descroix, L., Dourdain, A., Mazzei, L., Ouliac, B., ... Hérault, B. (2016). A methodological framework to assess the carbon balance of tropical managed forests. Carbon Balance and Management, 11(1), 15. doi:10.1186/s13021-016-0056-7

Piponiot, C., Sist, P., Mazzei, L., Peña-Claros, M., Putz, F. E., Rutishauser, E., ... Hérault, B. (2016). Carbon recovery dynamics following disturbance by selective logging in Amazonian forests. eLife, 5. doi:10.7554/eLife.21394

Poorter, L., Sande, M. T. van der, Arets, E. J., Ascarrunz, N., Enquist, B., Finegan, B., ... Peña-Claros, M. (2017). Biodiversity and climate determine the functioning of Neotropical forests. Global Ecology and Biogeography, 26(12), 1423-1434. doi:10.1111/geb.12668

Poorter, L., Rozendaal, D. M. A., Bongers, F., de Almeida-Cortez, J. S., Almeyda Zambrano, A. M., Álvarez, F. S., ... Westoby, M. (2019). Wet and dry tropical forests show opposite successional pathways in wood density but converge over time. Nature Ecology \& Evolution, 1. doi:10.1038/s41559-019-0882-6

Poorter, L., Wright, S. J., Paz, H., Ackerly, D. D., Condit, R., Ibarra-Manríquez, G., ... Others. (2008). Are functional traits good predictors of demographic rates? \{Evidence\} from five neotropical forests. Ecology, 89(7), 1908-1920. doi:10.1890/07-0207.1

Purves, D., \& Pacala, S. (2008). Predictive models of forest dynamics. American Association for the Advancement of Science, 320(5882), 1452-1453. doi:10.1126/science.1155359 
Putz, F. E., \& Redford, K. H. (2010). The importance of defining 'Forest': Tropical forest degradation, deforestation, long-term phase shifts, and further transitions. Biotropica, 42(1), 10-20. doi:10.1111/j.1744-7429.2009.00567.x

Qie, L., Telford, E. M., Massam, M. R., Tangki, H., Nilus, R., Hector, A., \& Ewers, R. M. (2019). Drought cuts back regeneration in logged tropical forests. Environmental Research Letters, 14(4), 45012. doi:10.1088/1748-9326/ab0783

Radchuk, V., Laender, F. De, Cabral, J. S., Boulangeat, I., Crawford, M., Bohn, F., ... Kramer-Schadt, S. (2019). The dimensionality of stability depends on disturbance type. Ecology Letters, 22(4), 674-684. doi:10.1111/ele.13226

Rutishauser, E., Hérault, B., Baraloto, C., Blanc, L., Descroix, L., Sotta, E. D., ... Sist, P. (2015). Rapid tree carbon stock recovery in managed Amazonian forests. Current Biology, 25(18), 787-788. doi:10.1016/j.cub.2015.07.034

Rüger, N., Huth, A., Hubbell, S. P., \& Condit, R. (2009). Response of recruitment to light availability across a tropical lowland rain forest community. Journal of Ecology, 97(6), 13601368. doi:10.1111/j.1365-2745.2009.01552.x

Sakschewski, B., Bloh, W. von, Boit, A., Poorter, L., Peña-Claros, M., Heinke, J., ... Thonicke, K. (2016). Resilience of Amazon forests emerges from plant trait diversity. Nature Climate Change, 6(11), 1032-1036. doi:10.1038/nclimate3109

Sánchez-Pinillos M, Coll L, De Cáceres M, Ameztegui A. (2016). Assessing the adaptive capacity of communities to natural disturbances on the basis of species response traits. Ecological Indicators 66, 76-85. doi:10.1016/j.ecolind.2016.01.024

Sande, M. T. van der, Arets, E. J., Peña-Claros, M., Hoosbeek, M. R., Cáceres-Siani, Y., Hout, P. van der, \& Poorter, L. (2018). Soil fertility and species traits, but not diversity, drive productivity and biomass stocks in a Guyanese tropical rainforest. Functional Ecology, 32(2), 461-474. doi:10.1111/1365-2435.12968 
Sande, M. T. van der, Poorter, L., Balvanera, P., Kooistra, L., Thonicke, K., Boit, A., ... Peña-Claros, M. (2017). The integration of empirical, remote sensing and modelling approaches enhances insight in the role of biodiversity in climate change mitigation by tropical forests. Current Opinion in Environmental Sustainability, 26(27), 69-76. doi:10.1016/j.cosust.2017.01.016

Sande, M. T. van der, Poorter, L., Kooistra, L., Balvanera, P., Thonicke, K., Thompson, J., ... PeñaClaros, M. (2017). Biodiversity in species, traits, and structure determines carbon stocks and uptake in tropical forests. Biotropica, 49(5), 593-603. doi:10.1111/btp.12453

Santiago, L. S., De Guzman, M. E., Baraloto, C., Vogenberg, J. E., Brodie, M., Hérault, B., ... Bonal, D. (2018). Coordination and trade-offs among hydraulic safety, efficiency and drought avoidance traits in Amazonian rainforest canopy tree species. New Phytologist, 218(3), 1015-1024. doi:10.1111/nph.15058

Schnitzer, S. A., \& Carson, W. P. (2016). Would Ecology Fail the Repeatability Test? BioScience, 66(2), 98-99. doi:10.1093/biosci/biv176

Silvertown, J. (2004). Plant coexistence and the niche. Trends in Ecology and Evolution, 19(11), 605-611. doi:10.1016/j.tree.2004.09.003

Simula, M. (2009). Towards defining forest degradation: comparative analysis of existing definitions. Forest Resources Assessment Working Paper, 154.

Sist, P., Rutishauser, E., Peña-Claros, M., Shenkin, A., Hérault, B., Blanc, L., ... Yamada, T. (2015). The Tropical managed forests Observatory: A research network addressing the future of tropical logged forests. Applied Vegetation Science, 18(1), 171-174. doi:10.1111/avsc.12125

Sullivan, M. J., Talbot, J., Lewis, S. L., Phillips, O. L., Qie, L., Begne, S. K., ... Zemagho, L. (2017). Diversity and carbon storage across the tropical forest biome. Scientific Reports, 7(39102). doi:10.1038/srep39102 
Tilman, D., Reich, P. B., Knops, J., Wedin, D., Mielke, T., \& Lehman, C. (2001). Diversity and Productivity in a Long-Term Grassland Experiment. Science, 294(5543). doi:10.1126/science.1060391

Tobner, C. M., Paquette, A., Gravel, D., Reich, P. B., Williams, L. J., \& Messier, C. (2016). Functional identity is the main driver of diversity effects in young tree communities. Ecology Letters, 19(6), 638-647. doi:10.1111/ele.12600

Turner, B.L., Brenes-Arguedas, T., Condit, R., 2018. Pervasive phosphorus limitation of tree species but not communities in tropical forests. Nature 555(7696), 15. doi:10.1038/s41586018-0099-x

Villéger, S. (2008). Dynamique de la diversité fonctionnelle des communautés de poissons (Lagune de Terminos, Mexique) (PhD thesis). Montpellier SupAgro, Montpellier.

Villéger, S., Mason, N. W. H., \& Mouillot, D. (2008). New multidimensional functional diversity indices for a multifaceted framework in functional ecology. Ecology, 89(8), 2290-2301. doi:10.1890/07-1206.1

Wright, S. J., Kitajima, K., Kraft, N. J., Reich, P. B., Wright, I. J., Bunker, D. E., ... Zanne, A. E. (2010). Functional traits and the growth-mortality trade-off in tropical trees. Ecology, 91(12), 36643674. doi:10.1890/09-2335.1

Zhang, Y., Chen, H. Y. H., \& Reich, P. B. (2012). Forest productivity increases with evenness, species richness and trait variation: A global meta-analysis. Journal of Ecology, 100(3), 742-749. doi:10.1111/j.1365-2745.2011.01944.x 


\section{Table captions}

Table 1 Species-specific parameters used in TROLL from Maréchaux \& Chave (2017). The data originate from the BRIDGE (Baraloto et al., 2010) and TRY (Kattge et al., 2011) datasets.

Table 2 Effects of functional diversity on forest resilience. Results of the linear models testing the effect of functional diversity indices (FDiv and FEve) on the resilience index $\left(I_{R}\right)$ for forest structure and functioning and for each level of disturbance intensity (disturb intensity $_{\text {in } \% \text { of }}$ total basal area). To meet the assumption of normality $I_{R}$ was log-transformed. Values of FDiv and FEve are model coefficients. Significant $P$ - values are in bold. ns, non-significant; $\mathrm{p}<0.1$; * $\mathrm{p}<0.05 ;^{* *} \mathrm{p}<0.01 ;^{* * *} \mathrm{p}<0.001$.

Table 3 Mean and standard deviation of the biodiversity net effect across simulations before the disturbance event (i.e. after 600 years of establishment) for different ecosystem variables.

\section{Figure captions}

Figure 1 Definition of the recovery function $\mathrm{R}$ and the resilience index $I_{R}$ shown for aboveground biomass dynamics for a simulation with disturb $_{\text {intensity }}=50 \%$.

Figure 2 Variation of forest resilience with taxonomic and functional diversity at different levels of disturbance intensity. Resilience index $I_{R}$ is represented versus functional diversity ( FDiv) for different levels of disturbance (disturb intensity $_{1}=25 \%, 50 \%$ and $75 \%$ of total basal area); the shape of the symbols varies with species richness. The intensity of the color of the symbols refers to functional evenness ( $F E v e$ ). Left column: $I_{R}$ computed for forest structure variables; right column: $I_{R}$ computed for forest functioning variables. Solid lines and grey areas show fitted relationships with their mean and variance of the form $I_{R} \sim N\left(\Theta_{F D i v} \times F d i v ; \sigma^{2}\right)$. For a clearer illustration of the variation of $I_{R}$ with FEve, see Appendix S4.

Figure 3 Post-disturbance trajectories of complementarity and selection effects on aboveground biomass at increasing levels of disturbance disturb $_{\text {intensity }}=25 \%, 50 \%$ and $75 \%$ 
of basal area loss). The net biodiversity (NE, in red), complementarity (CE in green) and selection (SE in blue) effects were normalized by the net effect of biodiversity in the control simulation $\left(\right.$ disturb $\left._{\text {intensity }}=0 \%\right)$. Solid lines represents the mean value whereas shaded areas represent the range of values across the 20 simulations with a species richness (SR) of 125 . The time axis has been square-root transformed to highlight dynamics in the first decades. 
Table 1 Species-specific parameters used in TROLL from Maréchaux \& Chave (2017). The data originate from the BRIDGE (Baraloto et al., 2010) and TRY (Kattge et al., 2011) datasets.

Abbreviation

LMA
$N_{m}$
$P_{m}$
wsg
$d b h_{\text {thresh }}$
$h_{\text {lim }}$
$a_{h}$

Description

leaf mass per area

leaf nitrogen content per

dry mass

leaf phosphorus content per

dry mass

wood specific gravity

diameter at breast height

threshold

asymptotic height

parameter of the tree

height-dbh allometry
Units of measure

$$
\begin{aligned}
& \text { g. } m^{-2} \\
& m g \cdot g^{-1}
\end{aligned}
$$

$m g \cdot g^{-1}$

$$
\text { g.cm }{ }^{-3}
$$

$m$

$m$

$m$ 
Table 2 Effects of functional diversity on forest resilience. Results of the linear models testing the effect of functional diversity indices (FDiv and FEve) on the resilience index $\left(I_{R}\right)$ for forest structure and functioning and for each level of disturbance intensity (disturb $b_{\text {intensity }}$ in of total basal area). To meet the assumption of normality $I_{R}$ was log-transformed. Values of FDiv and FE ve are model coefficients. Significant $P$ - values are in bold. $n s$, non-significant; $p<0.1 ;^{*} p<0.05$; ** $p<0.01{ }^{* * *} p<0.001$.

$$
\log \left(I_{R}\right)
$$
disturb $_{\text {intensity }}$
FDiv
FEve
$R^{2}$

structure

25

$0.29 * *$

0.13 n.s.

0.18

structure

50

$0.68 * *$

0.07 n.s.

0.27

structure

75

$0.7 * *$

$0.36 * *$

0.24

functioning $\quad 25$

$0.72 * *$

1.06 ***

0.51

functioning $\quad 50$

$0.98 * *$

$0.95 * *$

0.30

functioning

75

$0.8 *$

$1.33^{* * *}$

0.27 
Table 3 Mean and standard deviation of the biodiversity net effect across simulations before the disturbance event (i.e. after 600 years of establishment) for different ecosystem variables.

Ecosystem property

aboveground biomass

basal area

number of stems

number of stems above 10

$\mathrm{cm} \mathrm{dbh}$

growth primary production

net primary production

autotrophic respiration

during the day

autotrophic respiration

during the night
Net effect

$32.72 \pm 17.84$

$1.63 \pm 0.74$

$103.88 \pm 231.62$

$-6.82 \pm 13$

$0.15 \pm 0.05$

$-0.04 \pm 0.04$

$0.05 \pm 0.02$

$0.07 \pm 0.03$
Unit of measure

$$
\text { MgC.ha }{ }^{-1}
$$

$m^{2} \cdot h a^{-1}$

n.ha-1

n.ha $a^{-1}$

MgC.ha-1.yr ${ }^{-1}$

MgC.ha-1.yr ${ }^{-1}$

MgC.ha-1.yr ${ }^{-1}$

$M g C . h a^{-1} \cdot y r^{-1}$ 
Above-ground biomass ( $\mathrm{MgC} / \mathrm{ha})$

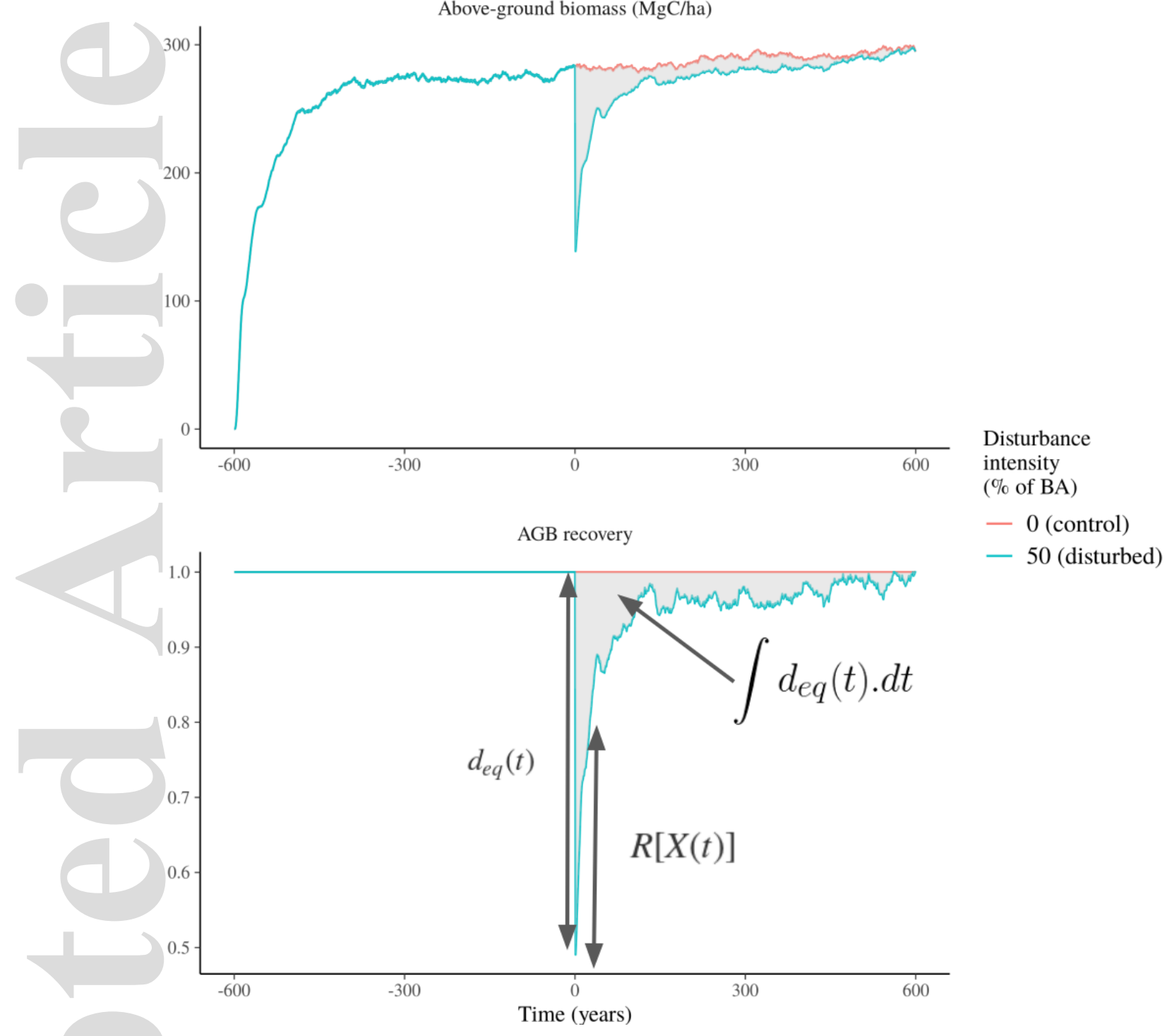

Figure 1 Definition of the recovery function $R$ and the resilience index $I_{R}$ shown for aboveground biomass dynamics for a simulation with disturb $b_{\text {intensity }}=50 \%$. 
disturbance: 25

Resilience: structure

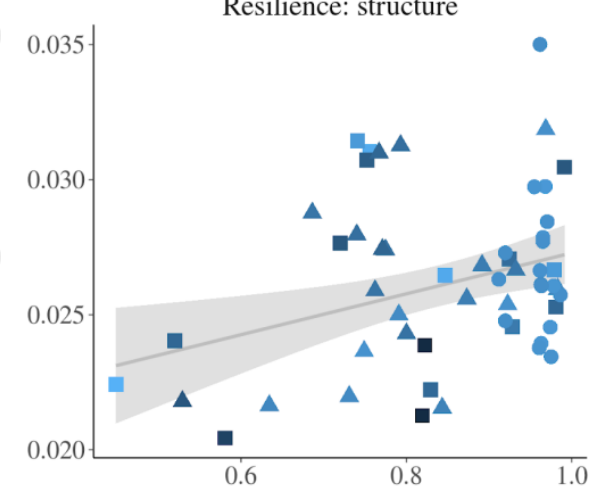

disturbance: 50

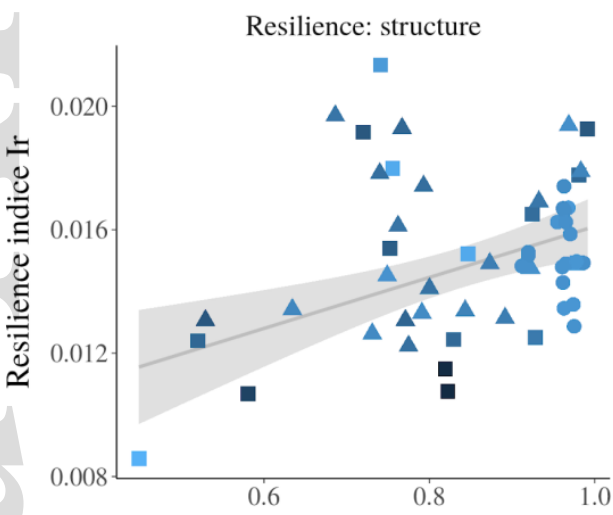

disturbance: 75

Resilience: structure

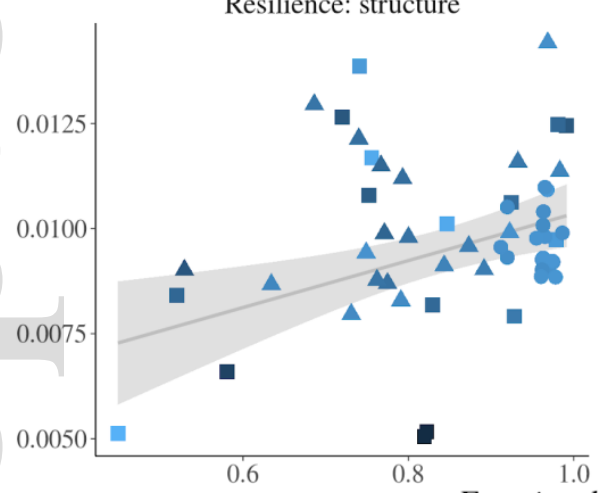

disturbance: 25

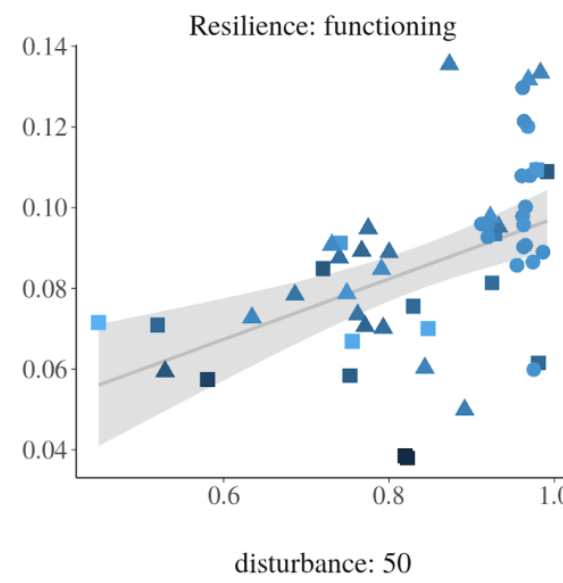

Resilience: functioning

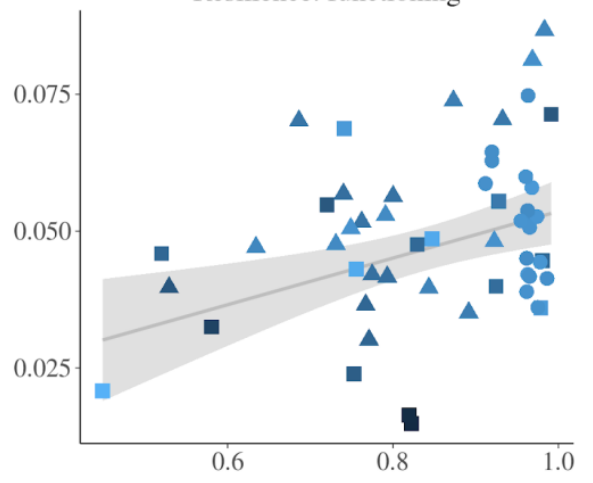

disturbance: 75

Resilience: functioning

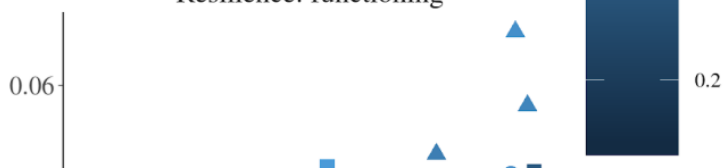

Species

richness

(SR)

\ $\quad 25$

Functional evenness (FEve)

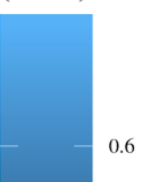

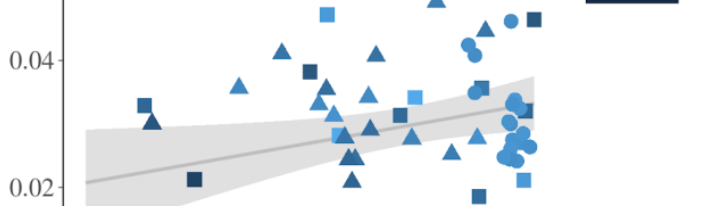

Figure 2 Variation of forest resilience with taxonomic and functional diversity at different levels of disturbance intensity. Resilience index $I_{R}$ is represented versus functional diversity (FDiv) for different levels of disturbance (disturb intensity $=25 \%, 50 \%$ and $75 \%$ of total basal area); the shape of the symbols varies with species richness. The intensity of the color of the symbols refers to 
functional evenness (FEve). Left column: $I_{R}$ computed for forest structure variables; right column: $I_{R}$ computed for forest functioning variables. Solid lines and grey areas show fitted relationships with their mean and variance of the form $I_{R} \sim N\left(\Theta_{F D i v} \times F d i v ; \sigma^{2}\right)$. For a clearer illustration of the variation of $I_{R}$ with FEve, see Appendix S4. 
SR: 125

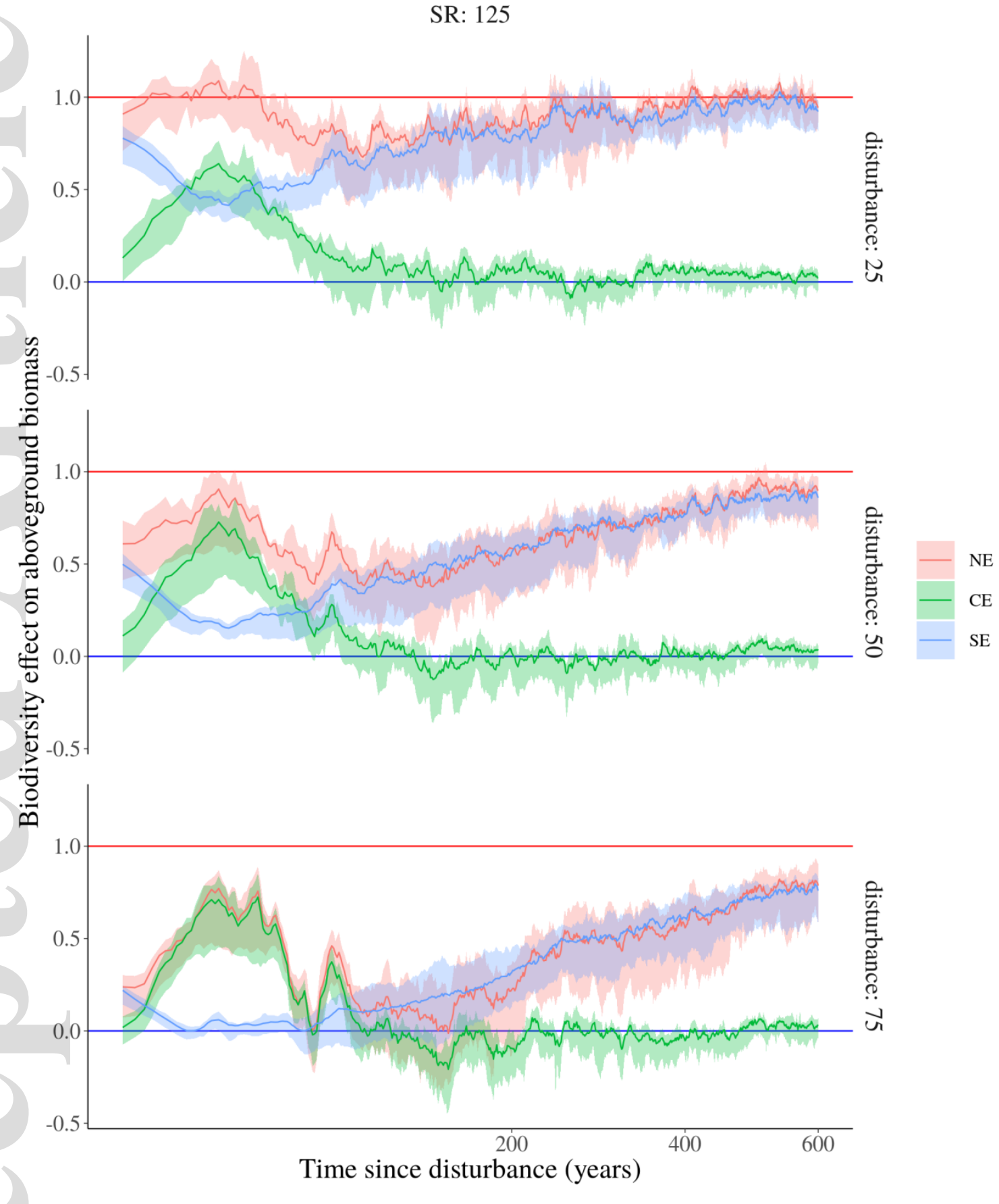

Figure 3 Post-disturbance trajectories of complementarity and selection effects on aboveground biomass at increasing levels of disturbance (disturb intensity $_{1}=25 \%, 50 \%$ and $75 \%$ of basal area loss). The net biodiversity (NE, in red), complementarity (CE in green) and selection (SE in blue) effects were normalized by the net effect of biodiversity in the control simulation (distur $b_{\text {intensity }}$ 
$=0 \%)$. Solid lines represents the mean value whereas shaded areas represent the range of values across the 20 simulations with a species richness (SR) of 125. The time axis has been square-root transformed to highlight dynamics in the first decades. 